\title{
ANALYSIS OF THE TONLE SAP FLOOD PULSE BASED ON REMOTE SENSING: HOW MUCH DOES TONLE SAP LAKE AFFECT THE MEKONG RIVER FLOOD?
}

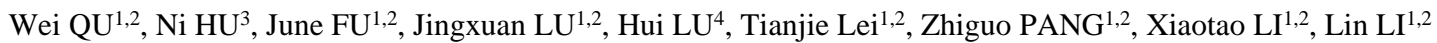

${ }^{1}$ China Institute of Water Resource and Hydropower Research, Beijing 10003 - (quwei, fuje, lujx, leitj, pangzg, lixt, lilin)@iwhr.com

${ }^{2}$ Research Center on Flood \& Drought Disaster Reduction of the Ministry of Water Resources, Beijing 100038

${ }^{3}$ Patent examination cooperation centre of sipo, Beijing - huni@sipo.gov.cn

${ }^{4}$ Tsinghua University, Beijing 100084 - luhui@ tsinghua.edu.cn

\section{Commission III, ICWG III/IVa}

KEY WORDS: Remote Sensing, Tonle Sap Lake, Flood, Mekong River, Water Storage

\begin{abstract}
:
The economic value of the Tonle Sap Lake Floodplain to Cambodia is among the highest provided to a nation by a single ecosystem around the world. The flow of Mekong River is the primary factor affecting the Tonle Sap Lake Floodplain. The Tonle Sap Lake also plays a very important role in regulating the downstream flood of Mekong River. Hence, it is necessary to understand its temporal changes of lake surface and water storage and to analyse its relation with the flood processes of Mekong River. Monthly lake surface and water storage from July 2013 to May 2014 were first monitored based on remote sensing data. The relationship between water surface and accumulative water storage change was then established. In combination with hydrological modelling results of Mekong River Basin, the relation between the lake's water storage and the runoff of Mekong River was analysed. It is found that the water storage has a sharp increase from September to December and, after reaching its maximum in December, water storage quickly decreases with a 38.8 billion $\mathrm{m}^{3}$ of drop in only half month time from December to January, while it keeps rather stable at a lower level in other months. There is a two months' time lag between the maximum lake water storage and the Mekong River peak flood, which shows the lake's huge flood regulation role to downstream Mekong River. It shows that this remote sensing approach is feasible and reliable in quantitative monitoring of data scarce lakes.
\end{abstract}

\section{INTRODUCTION}

The Tonle Sap Lake is the largest lake and wetland ecosystem in the Mekong River Basin, with a floodplain that extends over $15000 \mathrm{~km}^{2}$ and stores $50-80$ billion $\mathrm{m}^{3}$ of water from the Mekong River in wet season (MRC, 2005). The economic value of the Tonle Sap Lake Floodplain to Cambodia is among the highest provided to a nation by a single ecosystem around the world. The Tonle Sap Lake's biomass is equivalent to the sum of biomass in other parts of the Mekong River basin. In 1997, UNESCO put the Tonle Sap Lake Basin into the World Biosphere Reserve. The water exchange between Tonle Sap Lake and Mekong River was controlled by the water level of the main stream of Mekong River. So, the temporal change of the water area of Tonle Sap Lake can reflect the flood characteristic of the Lower Mekong River.

The annual flood pulse into the Tonle Sap Lake Floodplain ecosystem has shaped a unique mosaic of natural and agricultural habitats. These habitats not only support the largest fishery complex in Cambodia, but also decrease the flood affects and sea water invasion of Mekong River Delta. Mauricio analysed the changes in flooding and habitats in the Tonle Sap Lake(Combodia), and found that habitat cover shifts as a result of climate change. Kummu analyzed impacts on the flood characteristic, forests along the channel and the ecological protection area of the Tongle Sap Lake according to the runoff using a digital depth model. K. Vaz found that the upper reach flood plain of Mekong River changed obviously according to the regional water quantity balance using a regional climate model.
It is of great significance to study the changes in water volume and flood characteristics of Tonle Sap Lake. In this study, the monthly surface area changes of the Tonle Sap Lake were monitored using optical satellite imagery (HJ satellites). The water volume change from July 2013 to May 2014 were then calculated based on the digital elevation model (DEM). The runoff simulation of the Mekong river basin from June 2013 to May 2014 was simulated using a distributed hydrological model.

\section{STUDY AREA}

Tonle Sap Lake is located in the lower reaches of the Mekong River, northwest of Cambodia, and is the largest freshwater lake in South Asia (see Figure 1). The lake has important significance for flood control, economic development, and ecological values in Cambodia. More than 1 million people rely on the natural resources of the lake. There are three core Biosphere Reserves under the UNESCO and a Ramsar Wetland under the Ramsar Convention. The Tonle Sap Basin has an area of $85,000 \mathrm{~km}^{2}$, and its water production accounts for $6 \%$ of the average annual runoff in the Mekong River Basin.

Most of the water injected into Tonle Sap Lake comes from the main Mekong River. The tributaries of Tongle Sap River account for about $30 \%$ of the incoming water. $88 \%$ of the lake water is discharged into the mainstream of the Mekong River, $12 \%$ of the lake water is evaporated. When the water level of the Mekong River is lower than that of the Tonle Sap Lake, the water flows through the Tonle Sap River into the mainstream of the Mekong River. With the arrival of the rainy season in the Mekong River Basin, the water level of the Mekong River will increase, and the river water will begin to flow into the Tonle 
Sap Lake. After a period of accumulation, it will be released again to the main stream of the Mekong River, this greatly reducing the flood pressure in the lower Mekong Delta.

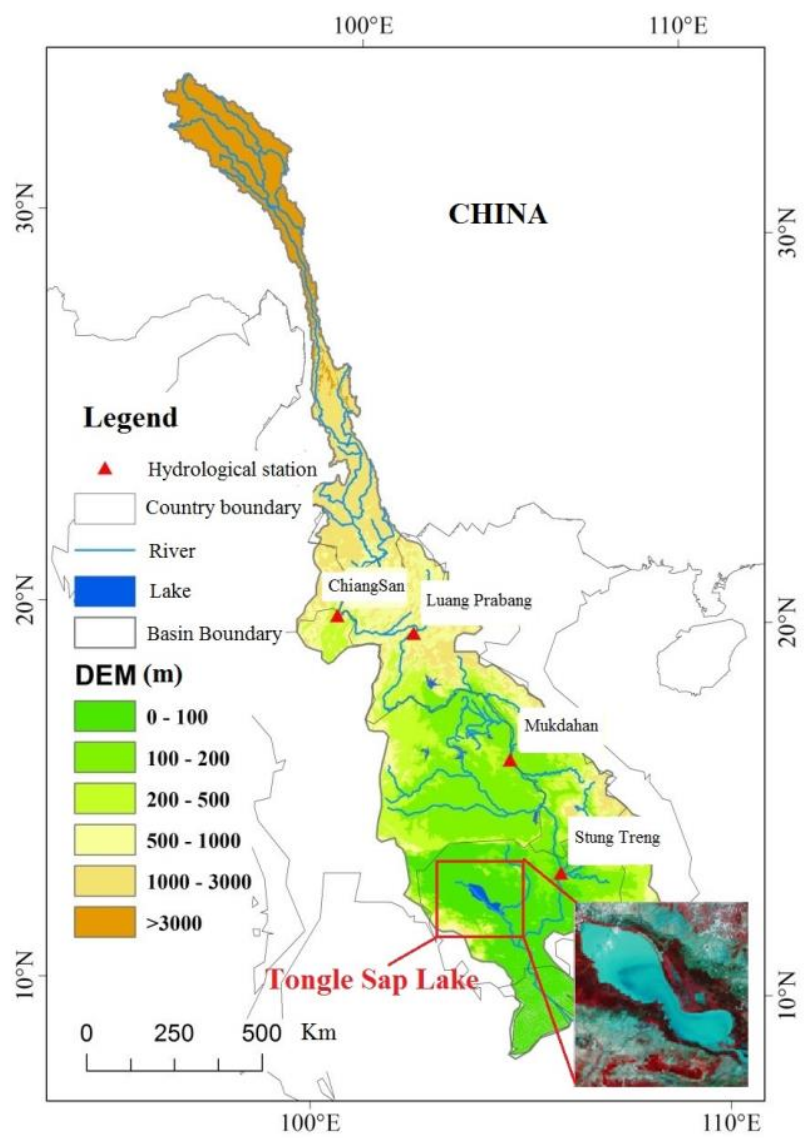

Figure.1 Location map of the Tonle Sap Lake and Mekong River Basin

\section{METHODS}

\subsection{Input data}

\begin{tabular}{|c|c|c|}
\hline Data Type & Resolution & Source \\
\hline $\begin{array}{c}\text { Satellite data } \\
\text { for monitoring }\end{array}$ & $30 \mathrm{~m}$ & HJ-1 \\
\hline $\begin{array}{c}\text { Reference } \\
\text { satellite data }\end{array}$ & $15 \mathrm{~m}$ & ETM+ \\
\hline DEM & $90 \mathrm{~m}$ & SRTM \\
\hline Land Cover & $1 \mathrm{~km}$ & $\begin{array}{c}\text { Global Land Cover } \\
\text { Characteristics Database } \\
\text { version 2.0 }\end{array}$ \\
\hline Soil Data & -- & $\begin{array}{c}\text { Digital Soil Map of the World } \\
\text { and Derived Soil Properties }\end{array}$ \\
\hline NDVI & $5600 \mathrm{~m}$ & MOD13C1 \\
\hline Precipitation & $0.25^{\circ}$ & TRMM \\
\hline Climate data & -- & $\begin{array}{c}\text { Climate data daily dataset } \\
\text { http://gis.ncdc.noaa.gov }\end{array}$ \\
\hline Runoff data & -- & $\begin{array}{c}\text { Daily Runoff Data of Chiang } \\
\text { Sam, Mukdahan and Pakse in } \\
\text { 2013 from MRC }\end{array}$ \\
\hline
\end{tabular}

Table.1 Data source table
For the monthly water area mapping methods, the HJ-1 CCD data were used. Their nominal spatial resolution is $30 \mathrm{~m}$. HJ-1 CCDs have three visible bands $(430-520 \mathrm{~nm}, 520-600 \mathrm{~nm}$, and $630-690 \mathrm{~nm})$ and one near-infrared band(760-900nm) which is sensitive to water. Landsat Mosaics (ETM +) data in 2000 with a spatial resolution of $15 \mathrm{~m}$ were used as the reference images for calibration. The SRTM data with a spatial resolution of $90 \mathrm{~m}$ was used as the digital terrain model The SRTM data was jointly measured by NASA and National Bureau of Surveying and Mapping (NIMA). Hydrological model input data includes $\operatorname{DEM}(90 \mathrm{~m})$, land cover data, Soil data and climate data etc. The detailed data information is listed as below.

\subsection{Water cover maps}

The normalized difference water index model was used to extract the monthly water cover area of Tonle Sap Lake from June 2013 to May 2014. Based on the ETM+ Mosaic data, the 12 series of $\mathrm{HJ}$ satellite multispectral data was geometrically corrected and all image errors were controlled within one pixel. The normalized difference water index (NDWI) was used to extract water area. The NDWI method used the difference in spectral characteristics between different wavelengths of water and background features, and established an operating formula and normalized it to expand this Spectral differences in order to achieve better distinction between water and background features. The NDWI formula is as follows:

$$
N D W I=(\text { Green }-N I R) /(\text { Green }+ \text { NIR })
$$

Where: Green is the green band, and NIR is the near-infrared band.

\subsection{Water volume change during a year}

The DEM data above a certain elevation was used to extract the water surface elevation of the relevant time period. Then, the area-elevation curve was established. In this curve, the water elevation corresponding to each time could be calculated. The change of the water storage amount of different time series was analyzed by using the area and elevation data, and the water area-water storage capacity curve is established. The change value of the lake water storage capacity in adjacent periods is calculated by using the curve of the area-water storage capacity of the lake.

The cumulative water storage change corresponding to the water elevation change could be calculated from Equation 3 .

$$
\begin{gathered}
Q_{H_{N}}-Q_{H_{N-1}}=\left(H_{N}-H_{N-1}\right) \times \frac{\left(S_{N}+S_{N-1}\right) \times 10^{6}}{2} \times 10^{-8} \\
Q_{H_{N}-H_{1}}=Q_{H_{2}-H_{1}}+Q_{H_{3}-H_{2}}+\ldots+Q_{H_{N}-H_{N-1}}
\end{gathered}
$$

Where: $\mathrm{H}_{\mathrm{N}-1}$ and $\mathrm{H}_{\mathrm{N}}$ are two adjacent water surface elevation values $(\mathrm{m})$ respectively, $\mathrm{S}_{\mathrm{N}-1}$ and $\mathrm{S}_{\mathrm{N}}$ are water areas $\left(\mathrm{km}^{2}\right)$ corresponding to $\mathrm{H}_{\mathrm{N}-1}$ and $\mathrm{H}_{\mathrm{N}},{ }_{H_{N}-H_{N-1}}$ is the the change of water storage volume $\left(100\right.$ million $\left.\mathrm{m}^{3}\right)$, and $Q_{H_{N}-H_{1}}$ is the cumulative change of water storage volume $\left(100\right.$ million $^{3}$ ) when the water level rises from $\mathrm{H}_{1}$ to $\mathrm{H}_{\mathrm{N}}$. 


\subsection{Rainfall-runoff simulation of the Mekong River Basin}

To further analyze the impact of the Mekong runoff changes on the water volume of Tonle Sap Lake, the 5-day NDVI dataset, daily precipitation dataset, and meteorological dataset were used as input data to construct the distributed hydrological model (Geomorphology-Based Hydrological Model, GBHM). Based on the physical mechanism of precipitation and runoff, the distributed watershed hydrological model GBHM uses the hillside as the basic unit to simulate the precipitation and runoff process. The model is based on terrain analysis and the concept of unit line. It uses the area equation and width equation to describe the geomorphological characteristics of the basin. The basin is divided into a series of internal uniform flow zones and flow bars to form a homogeneous slope flow unit, so that the model can reflect rainfall by the one-dimensional equations of water movement.

Model calibration and validation were based on the MRC hydrological station data. The simulation results of the model in the Mekong River Basin show that the annual water simulation accuracy is over $95 \%$, and the remote sensing data support rate is over $80 \%$. Finally, the daily runoff process of the Mekong River basin was simulated from June 2013 to May 2014.

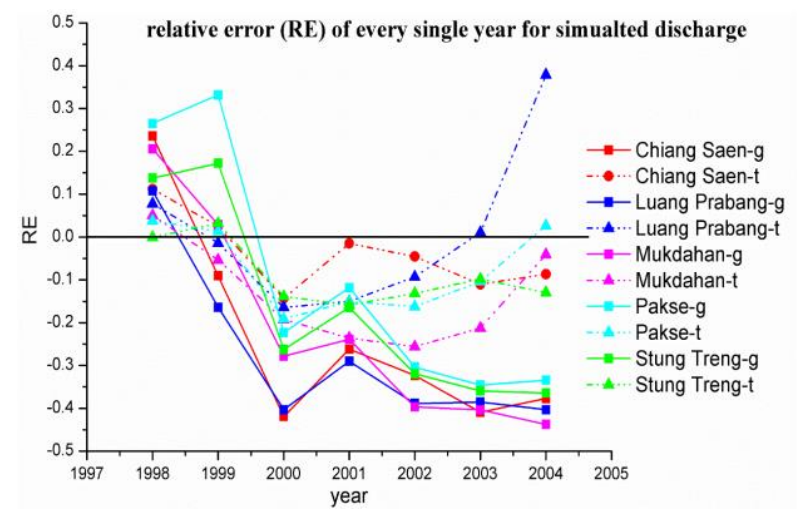

Figure.2 Comparison of RE of site-driven and remote-sensing driving simulation results

\section{RESULTS}

\subsection{Change of the water cover area}

Further analysis of changes in water cover area (Fig. 3) could reflect that the water area was increasing slowly from June to September. From September to December, the water area increased rapidly. The area of water in December 2013 reached $14,236 \mathrm{~km}^{2}$. This showed that with the advent of the rainy season, Tonle Sap Lake continued to accumulate a large number of floods from the main stream of the Mekong River. The area of water rapidly increased and flooded the vast flood plains around Tonle Sap Lake.

The water of Tonle Sap Lake drastically receded with an area of $11462 \mathrm{~km}^{2}$ from December 21, 2013 to January 6, 2014. Most of the water flowed back to the Mekong River through the Tonle Sap River and a small amount of water was evaporated or utilized in the vast floodplains of the Tonle Sap Lake. From January to May 2014, the area of the waters decreased slowly.

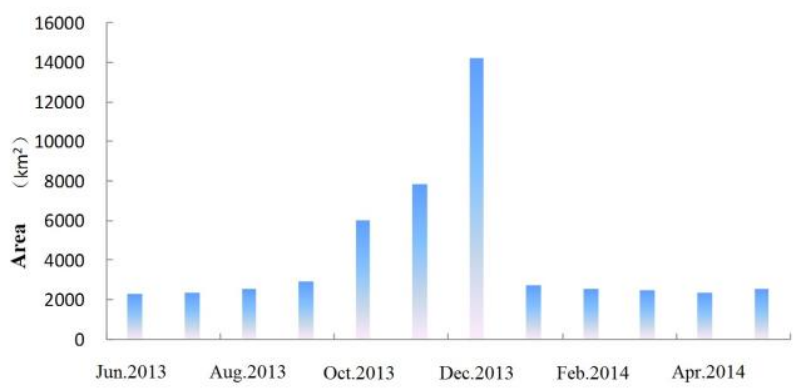

Figure. 3 Water surfaces changes diagram of the Tonle Sap Lake from June 2013 to May 2014

\subsection{Monitoring of the water volume change}

The water storage capacity of Tonle Sap had a continuous increase in the second half of 2013. As shown in Table 3, the water storage capacity increased 8.91 billion $\mathrm{m}^{3}$ from September 4 to October 11, 2013, and the average increase speed reached $2713.8 \mathrm{~m}^{3} / \mathrm{s}$. The amount of water storage increased 24.05 billion $\mathrm{m}^{3}$ from November 20 to December 21, 2013 , and the average increase speed reached $8698.6 \mathrm{~m}^{3} / \mathrm{s}$. The water storage capacity decreased from December 2013 to March 2014. The most obvious change occurred in January 2014 , and the water volume drastically decreased by 38.8 billion $\mathrm{m}^{3}$, and the average decrease speed reached 29938.3 $\mathrm{m}^{3} / \mathrm{s}$. The volume of water stored in January-March 2014 continued to decrease slowly.

The increase in water storage of Tonle Sap Lake mainly occurred from September to December 2013, while the decrease occurring mainly from December 2013 to January 2014. The change of water storage volume in other months was small. The rapid accumulation and release of the water fully demonstrated the great function of Tonle Sap in regulating floods of the lower Mekong River. The Tonle Sap Lake and its vast floodplains accumulate large flooding from the main stream of Mekong River. It plays a natural regulatory role in the runoff change below the Phnom Penh in the Mekong River.

\begin{tabular}{|c|c|c|}
\hline Date & $\begin{array}{c}\text { Changes in Water } \\
\text { storage }(100 \text { million } \\
\left.\mathrm{m}^{3}\right)\end{array}$ & $\begin{array}{r}\text { Average increase } \\
\text { or decrease speed } \\
\left(\mathrm{m}^{3} / \mathrm{s}\right)\end{array}$ \\
\hline 2013.06 .08 & - & - \\
\hline 2013.07 .13 & - & - \\
\hline 2013.08 .16 & - & - \\
\hline 2013.09 .04 & 11.1 & 2713.8 \\
\hline 2013.10 .11 & 89.1 & 1587.7 \\
\hline 2013.11 .20 & 53.5 & 8698.6 \\
\hline 2013.12 .21 & 240.5 & -29938.3 \\
\hline 2014.01 .06 & -388 & -185.2 \\
\hline 2014.02 .25 & -8.0 & -1085.1 \\
\hline 2014.03 .13 & -15.0 & - \\
\hline 2014.04 .19 & - & -1.8 \\
\hline 2014.05 .22 & 15.0 & - \\
\hline
\end{tabular}

Table 2. Change of water storage of the Tonle Sap Lake from July 2013 to May 2014 


\subsection{Rainfall-runoff simulation results of the Mekong River Basin}

From the north to the south, four major control sections were selected, included Chiang Saen in Thailand, Luang Prabang in Laos, Mukdahan in Thailand, and Stung Treng in Cambodia. Daily runoff changes from June 2013 to May 2014 were analyzed (Figure 3 ). The runoff results of the four sections showed that the river runoff mainly concentrated in the rainy season from June to October 2013, accounting for $73.4 \%$, $73.6 \%, 81.3 \%$ and $81.4 \%$ of the annual runoff. respectively. The annual total runoff of the Stung Treng control section is 433 billion $\mathrm{m}^{3}$, which is comparable to the historical period.

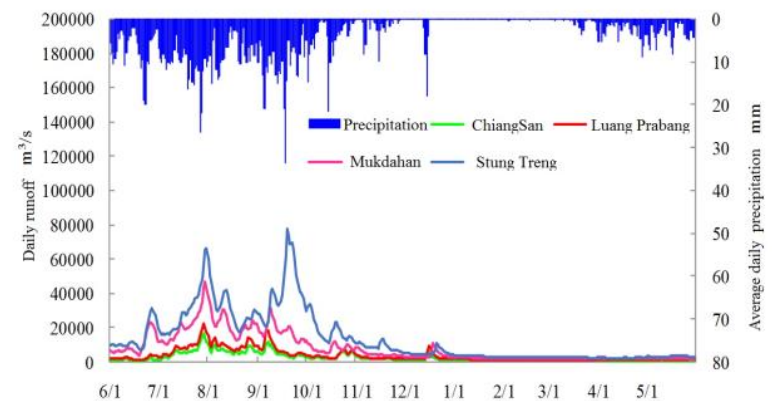

Figure 4. Daily runoff of major hydrological stations in Mekong River basin from June 2013 to May 2014

Based on the results of simulated runoff from remote sensing, the runoff at the control section of the Stung Treng Station was analyzed in Table. The yearly average daily runoff in Stung Treng is $13732 \mathrm{~m}^{3} / \mathrm{s}$, while the average daily runoff in wet season of Stung Treng is $27088 \mathrm{~m}^{3} / \mathrm{s}$, and the average daily runoff in dry season of Stung Treng is $4257 \mathrm{~m}^{3} / \mathrm{s}$.

\begin{tabular}{|c|c|c|}
\hline \multirow{2}{*}{ Time } & $\begin{array}{c}\text { Monitoring } \\
\text { Period }\end{array}$ & $\begin{array}{c}\text { Average Daily Runoff in } \\
\text { Stung Treng }\left(\mathrm{m}^{3} / \mathrm{s}\right)\end{array}$ \\
\hline \multirow{3}{*}{$2013.5-2014.6$} & Year & 13732 \\
\cline { 2 - 3 } & Wet Season & 27088 \\
\cline { 2 - 3 } & Dry Season & 4257 \\
\hline
\end{tabular}

Table 3. Averaged daily runoff in Stung Treng

The runoff depth and precipitation spatial distribution of the Mekong River basin from June 2013 to May 2014 are basically the same. The total trend of runoff and rainfall in the basin is decreasing from southeast to northwest, and the spatial and temporal changes of runoff are large, mainly affected by precipitation. The smallest runoff depth occurred in the Lancang River Basin, with a value of less than $500 \mathrm{~mm}$. The wet area with a runoff depth greater than $1000 \mathrm{~mm}$ is located in the west and east of Cambodia, the northern and southern regions of Laos, and the borders of Myanmar, Laos, and Vietnam.

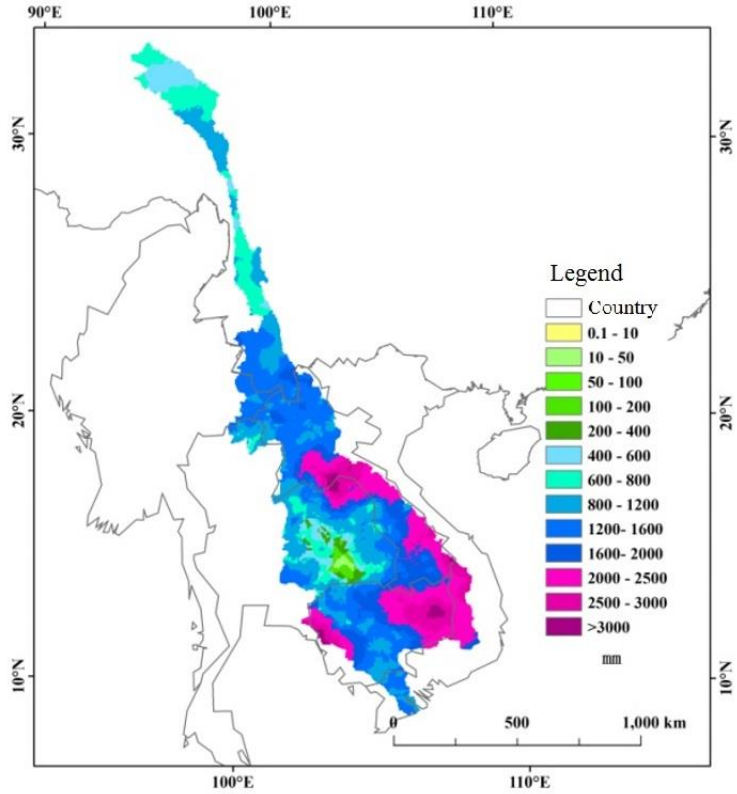

Figure 5. Precipitation of Mekong River Basin from2013.06 to 2014.05

The Mekong River basin has large latitudes and is affected by the southwest monsoon frequently. The runoff changes in the basin are mainly determined by the precipitation in Laos and in the coastal areas of Thailand and Cambodia. The runoff from the sea mainly comes from the Lower Mekong region. The watershed runoff module (water yield per unit area) is abundant in the upper reaches of the river, and the left bank is more abundant than the right bank. The maximum annual runoff depth is $2564 \mathrm{~mm}$, and the maximum annual rainfall is $3803 \mathrm{~mm}$. Both are located on the lower left bank.

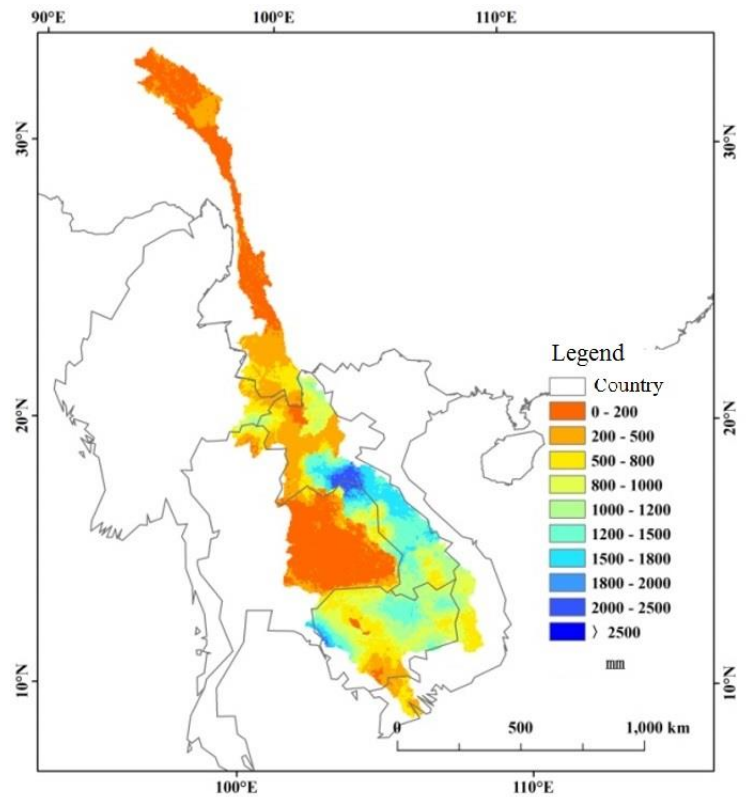

Figure 6. Runoff depth of Mekong River Basin from2013.06 to 2014.05 


\subsection{Relationship between Tonle Sap Lake flood and the Mekong River Flood}

From the annual precipitation process in the Mekong River Basin, it is known that from November to April of the following year is the dry season, and the amount of water in April is usually at the lowest point. From May to October is the rainy season. As the tropical monsoon enters from the south in May or June, the precipitation in the basin begins to increase. The runoff in the upstream reaches usually reaches its maximum in August or September, while the water level in the downstream reaches its highest level after October.

Tonle Sap Lake is located in the lower reaches of the Mekong River. When the water level of the main Mekong River is lower than that of the Tonle Sap Lake, the main stream flood will not affect the water volume of the Tonle Sap Lake until the level of the main stream continues to increase beyond the Tonle Sap Lake level. The water storage capacity of Tonle Sap Lake increased rapidly from October to December when the flood supplies from the mainstream of the Mekong River entered the lake. The water area reached a maximum in December. Compared to the flood peaks of the Lower Mekong River, there is a lag of about 2 months in the maximum water storage capacity of Tonle Sap Lake. There was a certain delay in the runoff compared to the precipitation process, and the flood peak of Tonle Sap Lake is later than the time of the Lower Mekong Flood.

When the water level of the Lower Mekong River was lower than the level in Tonle Sap Lake, the flood in Tonle Sap Lake returned to the Mekong River with a decrease speed of 29938 $\mathrm{m}^{3} / \mathrm{s}$ from December to January of next year. With rapid reduction, abundant nutrients were left for the floodplain. The long corridors of tall rivers adjacent to the shores of permanent shores are an important physical barrier between open lakes and flood plains.

\section{CONCLUSIONS}

The increase in water storage of Tonle Sap Lake mainly occurred from September to December, while the decrease occurring mainly from December to the next January. The change of water storage volume in other months was small. The rapid accumulation and release of the water demonstrated the great function of Tonle Sap Lake in regulating floods of the Lower Mekong River. The Tonle Sap Lake and its vast floodplains accumulate large flooding from the main stream of Mekong River. It plays a natural regulatory role in the runoff below the Phnom Penh in the Mekong River. It also receives $80 \%$ of the sediment and nutrients from the upper reaches of the Mekong River.

Combined with the results of precipitation and runoff simulation in the Mekong River Basin, the highest water level in the Tonle Sap Lake lags behind that of the Mekong mainstream by about two months. The huge natural adjustment capacity of Tonle Sap Lake has contributed to the relief of flooding in the lower reaches of the Mekong River. On the other hand, it has provided a steady stream of material accumulation for the vast floodplain of Tonle Sap Lake.

\section{ACKNOWLEDGEMENTS}

This work was supported by the National Keypoint Research and Invention Program of the Thirteenth Five-Plan
(2017YFB0504105), IWHR Research \& Development Support Program (JZ0145B612016\&JZ0145B032017), and the Natural Science Foundation of China (41601569\& 41501415). The authors would like to express appreciations to colleagues in our department for their valuable comments and other helps. The second author Ni Hu's contribution is equivalent to first author.

\section{REFERENCES}

Arias, M.E., Cochrane, T.A., Norton, D. et al. AMBIO (2013) 42: 864. https://doi.org/10.1007/s13280-013-0424-4

Arias, M.E., T.A. Cochrane, D. Norton, T.J. Killeen, and P. Khon. 2013. The flood pulse as the underlying driver of vegetation in the largest wetland and fishery of the Mekong Basin. Ambio 42, pp. 864-876

Campbell, I., C. Poole, W. Giesen, and J. Valbo-Jorgensen. Species diversity and ecology of Tonle Sap Great Lake, Cambodia[J]. Aquatic Sciences-Research Across Boundaries 2006(68), pp. 355-373.

Costa-Cabral, M.C., J.E. Richey, G. Goteti, D.P. Lettenmaier, C. Feldkötter, and A. Snidvongs.. Landscape structure and use, climate, and water movement in the Mekong River basin[J]. Hydrological Processes 2007 (22), pp. 1731-1746.

Fujii, H., Garsdal, H., Ward, P., Ishii, M., Morishita, K., Boivin, T., 2003. Hydrological roles of the Cambodian Floodplain of the Mekong River. International Journal of River Basin Management 1, pp. 1-14.

Hoang, L.P., Biesbroek, R., Tri, V.P.D. et al. Ambio (2018). https://doi.org/10.1007/s13280-017-1009-4

Kummu, Matti and Sarkkula, Juha. Impact of the Mekong River flow alteration on the Tonle Sap flood pulse[J]. A Journal of the Human Environment Ambio, 2008, 37(3), pp. 175-184.

K. Vastila. Impact of simulated climate change on flood pulses in the lower Mekong [J]. Journal of Water Resources and Hydropower, 2010, 31(8), pp. 5-9.

Mauricio E.Arias, Thomas A. Cochrane. Et.al Quantifying change in flooding and habitats in the Tonle Sap Lake (Combodia) caused by water infrastructure development and climate change in the Mekong Basin.[J]. Journal of Environmental Management, 2012(112), pp. 53-66.

Ramsar Convention on Wetlands. 2007. The list of wetlands of international importance. Ramsar Convention Secretariat, Gland, Switzerland.(http:www.ramsar.org/).

Sima, S. and Tajrishy, M. Using satellite data to extract volume-area-elevation relationships for Urmia Lake, Iran[J]. Journal of Great Lakes Research, 2013(39), pp. 90-99.

Wang, Xiaowei, Chen, Yan, Song, Lianchun, et al. Analysis of lengths, water areas and volumes of the Three Gorges Reservoir at different water levels using Landsat images and SRTM DEM data[J]. Quaternary International, 2013(304), pp. 115-125.

Zhong Huaping, Wang Jiansheng. Runoff Changes in the Mainstream of the Mekong River and their Impact on the Lower Reaches [J]. Journal of Water Conservancy and Hydroelectric Engineering, 2011(3), pp. 48-52. 